\title{
The cylindrospermopsin gene cluster of Aphanizomenon sp. strain 10E6: organization and recombination
}

Correspondence

Kjetill S. Jakobsen

k.s.jakobsen@bio.uio.no

Received 8 December 2009

Revised 16 April 2010

Accepted 28 April 2010

\author{
Anke Stüken ${ }^{1,2}$ and Kjetill S. Jakobsen ${ }^{2}$ \\ ${ }^{1}$ Department of Biology, Microbial Evolution Research Group (MERG), University of Oslo, \\ 0316 Oslo, Norway \\ ${ }^{2}$ Department of Biology, Centre for Ecological and Evolutionary Synthesis (CEES), University of \\ Oslo, 0316 Oslo, Norway
}

\begin{abstract}
Cylindrospermopsin (CYN), a potent hepatoxin, occurs in freshwaters worldwide. Several cyanobacterial species produce the toxin, but the producing species vary between geographical regions. Aphanizomenon flos-aquae, a common algae species in temperate fresh and brackish waters, is one of the three well-documented CYN producers in European waters. So far, no genetic information on the CYN genes of this species has been available. Here, we describe the complete CYN gene cluster, including flanking regions from the German Aphanizomenon sp. strain 10E6 using a full genome sequencing approach by 454 pyrosequencing and bioinformatic identification of the gene cluster. In addition, we have sequenced a $\sim 7 \mathrm{~kb}$ fragment covering the genes cyrC (partially), cyrA and cyrB (partially) of the same gene cluster in the CYN-producing Aphanizomenon sp. strains 10E9 and 22D11. Comparisons with the orthologous gene clusters of the Australian Cylindrospermopsis raciborskii strains AWT205 and CS505 and the partial gene cluster of the Israeli Aphanizomenon ovalisporum strain ILC-146 revealed a high gene sequence similarity, but also extensive rearrangements of gene order. The high sequence similarity (generally higher than that of $16 \mathrm{~S}$ rRNA gene fragments from the same strains), atypical GCcontent and signs of transposase activities support the suggestion that the CYN genes have been horizontally transferred.
\end{abstract}

\section{INTRODUCTION}

Cylindrospermopsin (CYN) is a potent hepatoxin produced by a number of cyanobacteria species. It was first characterized from an Australian strain of Cylindrospermopsis raciborskii (Ohtani et al., 1992) and was retrospectively suggested as the causative agent of the Palm Island mystery disease. This disease, which occurred in 1979 on Palm Island, Queensland, Australia, caused a sudden severe hepatitis-like illness in 138 children and some adults. It was traced back to a bloom of $C$. raciborskii in the main drinking water reservoir of the island (Bourke et al., 1983).

Since its first characterization from the Australian $C$. raciborskii strain, CYN has been detected in freshwater

Abbreviations: CYN cylindrospermopsin; HGT, horizontal gene transfer; IGS, intergenic spacer; ML, maximum likelihood; NRPS, non-ribosomal peptide synthetase; PKS, polyketide synthase.

The GenBank/EMBL/DDBJ accession number for the contig containing the cyr gene cluster is G0385961 and for the hyp gene cluster is HM131805.

Six supplementary tables, showing primer sequences and sequence identity data, and two supplementary figures, showing $\mathrm{ML}$ analyses of $c y r B / a o a B$ and $c y r A / a o a A$ genes, are available with the online version of this paper. bodies around the world, including New Zealand (Stirling \& Quilliam, 2001), South, Central and North America (Berry \& Lind, 2009; Burns et al., 2002; Carmichael et al., 2001), Asia (Chonudomkul et al., 2004; Li et al., 2001a) and Europe (e.g. Fastner et al., 2003). In addition to $C$. raciborskii, the cyanobacterial species Umezakia natans (Harada et al., 1994), Aphanizomenon (Aph.) ovalisporum (Banker et al., 1997; Shaw et al., 1999; Wörmer et al., 2008; Yilmaz et al., 2008), Raphidiopsis curvata (Li et al., 2001b), Aphanizomenon flos-aquae (Preußel et al., 2006), Anabaena (A.) lapponica (Spoof et al., 2006) and Lyngbya wollei (Seifert et al., 2007) have been shown to synthesize the toxin.

CYN $\left(\mathrm{C}_{15} \mathrm{H}_{21} \mathrm{~N}_{5} \mathrm{O}_{7} \mathrm{~S}\right)$ is a highly water-soluble alkaloid with a tri-cyclic guanidine group and an uracil ring attached at C-7 (Ohtani et al., 1992). Isotope-labelled precursor feeding experiments have shown that CYN is most likely synthesized by the interplay of non-ribosomal peptide synthetase (NRPS) and polyketide synthase (PKS) complexes and that guanidinoacetate is the starter unit for its biosynthesis (Burgoyne et al., 2000). PKS and NRPS genes putatively involved in the biosynthesis of CYN have been independently identified in C. raciborskii (Schembri 
et al., 2001) and Aph. ovalisporum (Shalev-Alon et al., 2002). Further, an amidinotransferase gene, whose gene product is suggested to catalyse the synthesis of the guanidinoacetate starter unit, has been characterized in Aph. ovalisporum (Shalev-Alon et al., 2002).

The entire putative CYN gene cluster was first characterized from the Australian C. raciborskii strain AWT205 (Mihali et al., 2008). The cluster spans $43 \mathrm{~kb}$ and contains 15 ORFs, including four PKSs, one PKS/ NRPS hybrid and one amidinotransferase. The first three steps in the CYN biosynthesis involve an amidinotransferase, a PKS/NRPS hybrid and a PKS. In $C$. raciborskii, these three ORFs have been denoted $c y r A, c y r B$ and $c y r C$, respectively, and correspond to the orthologues denoted aoaA, aoaB and aoaC in Aph. ovalisporum (Mihali et al., 2008). Recently, a second CYN gene cluster has been described from the Australian C. raciborskii strain CS-505. The two C. raciborskii gene clusters show perfect synteny and very high sequence conservation (Stucken et al., 2010).

Aph. flos-aquae and Aphanizomenon gracile are common cyanobacterial species of temperate fresh and brackish waters and have the capacity to form mass developments. In Germany, CYN-producing and -non-producing strains of these species have been reported to co-occur, and CYNproducing strains of both phenotypes have been isolated (Preußel et al., 2006; Preußel, 2007; Stüken et al., 2009). Together with Aph. ovalisporum and A. lapponica isolates from Spain and Finland, respectively (Spoof et al., 2006; Wörmer et al., 2008), these CYN-producing Aphanizomenon sp. isolates are the only confirmed CYN-producing species in Europe. C. raciborskii does occur in the same water bodies (Fastner et al., 2003, 2007; Rücker et al., 2007), but so far, CYN-producing C. raciborskii strains have only been isolated from Australian and Asian waters (e.g. Berger et al., 2006; Bernard et al., 2003; Fastner et al., 2003; Saker et al., 2003; Yilmaz et al., 2008).

Recently, a number of studies have reported the cooccurrence of CYN and Aphanizomenon sp. in European water bodies (Bláhová et al., 2008; Brient et al., 2009; Kokocinski et al., 2009; Messineo et al., 2009). However, no genetic data on the CYN genes of Aphanizomenon sp. are currently available, thus rendering studies on the evolution and distribution of this gene cluster in Aphanizomenon sp. impossible.

We have sequenced and characterized the entire CYN gene cluster in Aphanizomenon sp. strain 10E6 (Preußel et al., 2006) using a massive parallel (454) pyrosequencing approach. In addition, we have sequenced a $\sim 7 \mathrm{~kb}$ fragment of the same gene cluster in Aphanizomenon sp. strains 10E9 and 22D11 covering the entire $c y r A$ and partial $c y r B$ and $c y r C$ sequences. To study the evolution and processes associated with the distribution of this gene cluster, we have compared the Aphanizomenon sp. 10E6 gene cluster and its flanking regions with the orthologous gene clusters of $C$. raciborskii strains AWT205 and CS-505 and to the partial aoa gene cluster of Aph. ovalisporum strain ILC-146. Further, we have phylogenetically analysed all available cyr and aoa gene sequences and have compared the results with a phylogeny of the cyanobacterial RNA polymerase gene rpoC1. Our data show extensive recombination, signs of transposase activities, atypical GC content and possible horizontal gene transfer events.

\section{METHODS}

Strain cultivation and DNA isolation. Aphanizomenon sp. strains 06D11, 10E6, 10E9, 14E6, 16D11 and 22D11 were provided by Karina Preußel (Federal Environmental Agency, Berlin, Germany) and cultivated in $\mathrm{Z} 8$ medium, at $20^{\circ} \mathrm{C}$, at a photon flux density of $65 \mu \mathrm{mol}$ of photons $\mathrm{m}^{-2} \mathrm{~s}^{-1}$ and under $12 \mathrm{~h} / 12 \mathrm{~h}$ light: dark cycles. Strains were not axenic. Strain 10E6 has been placed in the NIVA culture collection, Oslo, Norway, and is available under the strain number NIVA-CYA626. Prior to genomic DNA isolation, cells were filtered over $3 \mu \mathrm{m}$ membrane filters (Millipore), resuspended in culture medium (sterile, diluted to $25 \%$ of original concentration) and centrifuged (30 min at $16100 \mathrm{~g}$ ). The supernatant was discarded, and the pellet was resuspended in $1 \times$ TE-buffer and frozen at $-20{ }^{\circ} \mathrm{C}$. The DNA isolation was performed as follows: the cells were thawed under vortexing, lysozyme $\left(5 \mathrm{mg} \mathrm{ml}^{-1}\right)$ was added (incubation $50{ }^{\circ} \mathrm{C}, 30 \mathrm{~min}$ ), followed by incubation with RNaseA (Omega Bio-Tek; $\left.50{ }^{\circ} \mathrm{C}, 30 \mathrm{~min}\right)$ and then Proteinase $\mathrm{K}\left(2 \mathrm{mg} \mathrm{ml}^{-1}\right.$; $60{ }^{\circ} \mathrm{C}$, $60 \mathrm{~min}$ ). Subsequently, 1 vol. chloroform-isoamyl alcohol [24:1 (v/ v)] was added, and the sample was mixed and centrifuged $(5 \mathrm{~min}$ at $16100 \mathrm{~g}$ ). The upper layer was transferred and the chloroformisoamyl alcohol procedure was repeated twice. Sodium acetate $(3 \mathrm{M}$; $\mathrm{pH}$ 5.2, $0.3 \mathrm{M}$ final concentration) and 0.7 vol. 2-propanol were added; the solution was mixed, incubated (room temperature, $30 \mathrm{~min}$ ) and centrifuged (30 min at $16100 \mathrm{~g}$ ). The DNA pellet was washed twice with ethanol $(70 \%)$, dried at room temperature and dissolved in TE buffer.

Identification of the CYN biosynthesis gene cluster of Aphanizomenon sp. 10E6. Whole genome shotgun sequencing was carried out at the Ultra-high Throughput Sequencing Platform (UTSP) at the Centre for Ecological and Evolutionary Synthesis (CEES), Dept of Biology, University of Oslo, using a GS FLX instrument (Roche). Library preparation, amplification and pyrosequencing were performed according to the manufacturer's instructions, using GLS FLX standard chemistry. One full plate was used for shotgun sequencing and a half plate was used for $3 \mathrm{~kb}$ paired-end sequencing. In addition, a half plate of $3 \mathrm{~kb}$ paired-end sequencing was performed at 454 Life Sciences (Branford). In paired-end sequencing, both ends of the DNA fragment are sequenced. This information can be used to sort and orientate contigs, which is important in reconstructing the original genome sequence. In shotgun sequencing, contigs are defined as a set of overlapping DNA segments derived from a single genetic source. A series of contigs that are sorted into the right order and orientation, but not necessarily connected in one continuous stretch of sequence, are referred to as scaffold (http://454.com/glossary/index.asp). The newbler assembler (gsAssembler) from Roche/454 (version 2.00.22) was used to assemble the reads. The assembly parameters were set to a minimum alignment identity of $98 \%$ with a minimum alignment overlap of $60 \mathrm{bp}$. To identify the CYN gene cluster, all contigs were compared to the (partial) aoa genes from Aph. ovalisporum ILC-146 (AF395828), the cyr genes from C. raciborskii AWT205 (EU140798) and the (partial) $c y r A-C$ sequences obtained from the Aphanizomenon sp. strains (see below) using the BLASTN and BLASTX algortithms (Altschul et al., 1997) on the University of Oslo Bioportal (http:// www.bioportal.uio.no). 
Table 1. Cyanobacterial strains for which CYN synthesis and the presence cyrA/aoaA and/or cyrB/aoaB genes (or fragments thereof) have been investigated

+, CYN-producing/gene present; -, CYN-non-producing/gene absent. ND, no data; PS, present study. References (given in parentheses) are as follows: 1, Preußel (2007); 2, Preußel et al. (2006); 3, Haande et al. (2008); 4, Stucken et al. (2010); 5, Hawkins et al. (1997); 6, Schembri et al. (2001); 7, Rasmussen et al. (2008); 8, Saker \& Griffiths (2000); 9, Fastner et al. (2003); 10, Fergusson \& Saint (2003); 11, Pollingher et al. (1998); 12, ShalevAlon et al. (2002); 13, Ballot et al. (2010); 14, Kellmann et al. (2006); 15, Neilan et al. (2003); 16, Harada et al. (1994); 17, Berger et al. (2006); 18, Yilmaz et al. (2008); 19, Bernard et al. (2009); 20, Wilson et al. (2000); 21, Lagos et al. (1999); 22, Valério et al. (2005); 23, Saker et al. (1999).

\begin{tabular}{|c|c|c|c|c|}
\hline Organism & Country & CYN & cyrB/aoaB & cyrA/aoaA \\
\hline \multicolumn{5}{|l|}{ Anabaena } \\
\hline \multicolumn{5}{|l|}{ Anabaena bergii } \\
\hline Three strains & Germany & $-(13)$ & $-(13)$ & $\mathrm{ND}$ \\
\hline ANA360A & Australia & $-(7)$ & $-(7)$ & $-(7)$ \\
\hline ANA360D & Australia & $-(10)$ & $-(10)$ & ND \\
\hline ANA360H & Australia & $-(7)$ & $+(7)$ & $-(7)$ \\
\hline ANA366A & Australia & $-(10)$ & $-(10)$ & $-(7)$ \\
\hline Anabaena circinalis, ANA118C & Australia & $-(6)$ & $-(6)$ & ND \\
\hline Anabaena crassa, one strain & Germany & $-(13)$ & $-(13)$ & $\mathrm{ND}$ \\
\hline Anabaena flos-aquae, two strains & Germany & $-(13)$ & $-(13)$ & $\mathrm{ND}$ \\
\hline Anabaena lemmermanii, three strains & Germany & $-(13)$ & $-(13)$ & ND \\
\hline Anabaena planctonica, 22 strains & Germany & $-(13)$ & $-(13)$ & ND \\
\hline Anabaena sp., one strain & Germany & $-(13)$ & $-(13)$ & $\mathrm{ND}$ \\
\hline \multicolumn{5}{|l|}{ Anabaenopsis } \\
\hline Anabaenopsis elenkinii, two strains & Germany & $-(13)$ & $-(13)$ & $\mathrm{ND}$ \\
\hline \multicolumn{5}{|l|}{ Aphanizomenon } \\
\hline \multicolumn{5}{|l|}{ Aphanizomenon cf. klebahnii } \\
\hline NIVA-CYA 364-365 & Hungary & $-(\mathrm{PS})$ & $-(\mathrm{PS})$ & $-(\mathrm{PS})$ \\
\hline \multicolumn{5}{|l|}{ Aphanizomenon flos-aquae } \\
\hline Eighteen strains & Germany & $-(13)$ & $-(13)$ & $\mathrm{ND}$ \\
\hline NIVA-CYA 142 & Canada & $-(\mathrm{PS})$ & - (PS) & $-(\mathrm{PS})$ \\
\hline \multicolumn{5}{|l|}{ Aphanizomenon gracile } \\
\hline Thirty-four strains & Germany & $-(13)$ & $-(13)$ & ND \\
\hline NIVA-CYA 103 & Norway & $-(\mathrm{PS})$ & $-(\mathrm{PS})$ & $-(\mathrm{PS})$ \\
\hline NIVA-CYA 338 & Hungary & $-(\mathrm{PS})$ & $-(\mathrm{PS})$ & $-(\mathrm{PS})$ \\
\hline \multicolumn{5}{|l|}{ Aphanizomenon issatschenkoi } \\
\hline Six strains & Germany & $-(13)$ & $-(13)$ & ND \\
\hline APH016B & Australia & $-(24)$ & $-(23)$ & $-(23)$ \\
\hline CAWBG02 & New Zealand & $-(23)$ & $+(23)$ & $+(23)$ \\
\hline \multicolumn{5}{|l|}{ Aphanizomenon ovalisporum } \\
\hline ANA283A* & Australia & $+(6)$ & $+(6)$ & $+(7)$ \\
\hline ANA366B ${ }^{*}$ & Australia & $+(10)$ & $+(10)$ & $\mathrm{ND}$ \\
\hline APH031E, APH031G, APH035C & Australia & $+(7)$ & $+(10)$ & $+(7)$ \\
\hline АPH033C, АРH035F & Australia & $+(10)$ & $+(10)$ & $+(7)$ \\
\hline FAS-AP1 & USA & $+(18)$ & $+(18)$ & $\mathrm{ND}$ \\
\hline ILC-164 & Israel & $+(11)$ & $+(12)$ & $+(12)$ \\
\hline MS1 & Israel & $+(22)$ & $+(22)$ & $+(22)$ \\
\hline \multicolumn{5}{|l|}{ Aphanizomenon sp. } \\
\hline 06D11, 14E6, 16D11 & Germany & $-(1)$ & $-(1)$ & $-(\mathrm{PS})$ \\
\hline 10E6, 10E9, 22D11 & Germany & $+(2)$ & $+(2)$ & $+(\mathrm{PS})$ \\
\hline NIVA-CYA 638-641 & Norway & $-(\mathrm{PS})$ & $-(\mathrm{PS})$ & $-(\mathrm{PS})$ \\
\hline \multicolumn{5}{|l|}{ Cylindrospermopsis } \\
\hline \multicolumn{5}{|l|}{ Cylindrospermopsis curvispora } \\
\hline Two strains & Senegal & $-(17)$ & $-(17)$ & ND \\
\hline \multicolumn{5}{|l|}{ Cylindrospermopsis raciborskii } \\
\hline Nineteen strains & Senegal & $-(17)$ & $-(17)$ & ND \\
\hline 4799 & Portugal & $-(15)$ & $-(14)$ & $-(14)$ \\
\hline AQS & Australia & $+(22)$ & $+(22)$ & $+(22)$ \\
\hline AWT205 & Australia & $+(5)$ & $+(6)$ & $+(14)$ \\
\hline
\end{tabular}


Table 1. cont.

\begin{tabular}{|c|c|c|c|c|}
\hline Organism & Country & CYN & cyrB/aoaB & cyrA/aoaA \\
\hline Brazil1 & Brazil & $-(10)$ & $-(10)$ & ND \\
\hline Caia & Portugal & $-(15)$ & $-(14)$ & $-(14)$ \\
\hline CS-505 & Australia & $+(4)$ & $+(4)$ & $+(4)$ \\
\hline Cyli-19, $-31,-42,-53,-94$ & Germany & $-(9)$ & $-(10)$ & $-(7)$ \\
\hline Cyli-29 & Germany & $-(9)$ & $-[+](10)[(7)]$ & $-(7)$ \\
\hline CYP003A & Australia & $-(6)$ & $-(6)$ & $-(7)$ \\
\hline СYР003B, СYР025C & Australia & $+(6)$ & $+(6)$ & $\mathrm{ND}$ \\
\hline $\begin{array}{l}\text { CYP003K, CYP020A, CYP020B, CYP023A, CYP023E, } \\
\text { CYP025B, CYP026J }\end{array}$ & Australia & $+(6)$ & $+(6)$ & $+(7)$ \\
\hline CYP005E & Australia & $+(6)$ & $+(6)$ & $+(14)$ \\
\hline CYP014A, CYP015A & Australia & $-(6)$ & $-(6)$ & $-(7)$ \\
\hline FL-D, -F, -G, -I & USA & $-(18)$ & $-(14)$ & $-(14)$ \\
\hline GERM1, GERM2 & Germany & $-(15)$ & $-(14)$ & $-(14)$ \\
\hline Goon & Australia & $+(8)$ & $+(14)$ & $+(14)$ \\
\hline HUNG1 & Hungary & $-(14)$ & $+(14)$ & $-(14)$ \\
\hline HUNG2 & Hungary & $-(14)$ & $-(14)$ & $-(14)$ \\
\hline LJ & Australia & $-(8)$ & $-(22)$ & $-(22)$ \\
\hline LMECYA132-135, 168 & Portugal & $-(22)$ & $-(22)$ & $-(22)$ \\
\hline Marau1 and Marau2 & Portugal & $-(15)$ & $-(14)$ & $-(14)$ \\
\hline NIVA-CYA 225, 352-354, 399 & Hungary & $-(\mathrm{PS})$ & $-(\mathrm{PS})$ & $-(\mathrm{PS})$ \\
\hline NIVA-CYA 506-511 & Uganda & $-(3)$ & $-(3)$ & $\mathrm{ND}$ \\
\hline PMC99.06 & Mexico & $-(17)$ & $-(17)$ & $\mathrm{ND}$ \\
\hline \multicolumn{5}{|l|}{ Nodularia } \\
\hline Nodularia spumigena CS-590 & Australia & $-(7)$ & $-(7)$ & $-(7)$ \\
\hline Nodularia spumigena PCC73104 & Canada & $-(6)$ & $-(6)$ & $\mathrm{ND}$ \\
\hline \multicolumn{5}{|l|}{ Limnothrix } \\
\hline Limnothrix sp. AC0233 & Australia & $-(19)$ & $-(19)$ & $-(19)$ \\
\hline \multicolumn{5}{|l|}{ Raphidiopsis } \\
\hline Raphidiopsis brookii D9 & Brazil & $-(4)$ & $-(4)$ & $-(4)$ \\
\hline \multicolumn{5}{|l|}{ Umezakia } \\
\hline Umezakia natans TAC101 & Japan & $+(16)$ & $+(14)$ & $+(14)$ \\
\hline
\end{tabular}

*Originally identified as A. bergii, reclassified as Aph. ovalisporum (Stüken et al., 2009).

ORFs were identified and annotated using the NCBI ORF Finder (http://www.ncbi.nlm.nih.gov/projects/gorf/).

Amplification of cyr genes. Based on the aoa and cyr genes of Aph. ovalisporum ILC-146 (AF395828) and C. raciborskii AWT205 (EU140798), primers were designed that amplified the entire $c y r A$ and partial cyrC $(\sim 1000 \mathrm{bp})$ and $c y r B(\sim 4200 \mathrm{bp})$ gene sequences in Aphanizomenon species. PCRs were carried out on the CYN-producing strains 10E6, 10E9 and 22D11 (Preußel et al., 2006) and the non-CYNproducing strain 14E6 (Preußel, 2007). Reactions were carried out in
$50 \mu$ volumes containing 1 unit $10 \times$ BD Advantage 2 PCR buffer $(B D$ Biosciences), $250 \mu \mathrm{M}$ of each dNTP, 25 pmol of each primer (Supplementary Table S1, available with the online version of this paper), 0.5 units $50 \times \mathrm{BD}$ Advantage 2 Polymerase Mix (BD Biosciences) and 10-50 ng DNA. Cycling conditions were: $95{ }^{\circ} \mathrm{C}$ for $60 \mathrm{~s}, 30 \times\left(94{ }^{\circ} \mathrm{C}\right.$ for $30 \mathrm{~s}, 65{ }^{\circ} \mathrm{C}$ for $60 \mathrm{~s}, 68{ }^{\circ} \mathrm{C}$ for a variable time, see Supplementary Table S1), $70{ }^{\circ} \mathrm{C}$ for $720 \mathrm{~s}, 8{ }^{\circ} \mathrm{C}$ hold. PCR products were visualized on $1 \%$ agarose gels stained with ethidium bromide. PCR products were cleaned with ExoSAP-IT (USB Corporation) and then sequenced directly. Sequencing primers are listed in Supplementary Table S2. Sequences were 
analysed and assembled using the software programs Sequencher version 4.8 and CLC DNA Workbench version 5.0.2.

Further, 18 Aphanizomenon and Cylindrospermopsis strains obtained from the Norwegian Institute for Water Research (NIVA) culture collection and six Aphanizomenon sp. strains received from K. Preußel (Table 1) were investigated for the presence of $c y r A$ and $c y r B$ gene fragments. PCRs were carried out in $20 \mu \mathrm{l}$ reactions using the Qiagen HotStarTaq Plus PCR kit. The cyrB and $c y r A$ fragments were amplified using the primer pairs M13 and M14 (Schembri et al., 2001), and cylatF and cylatR (Kellmann et al., 2006), respectively.

CYN ELISA. The 18 NIVA strains (Table 1) were tested for CYN synthesis with the CYN ELISA from Abraxis (Abraix LLC). Aphanizomenon sp. strains 10E6 and 14E6 were included as positive and negative controls, respectively. The ELISA was carried out according to the manufacturer's instructions. Prior to the test, $2 \mathrm{ml}$ culture material from each strain was frozen and thawed three times to break the cells and release the toxin into the medium. After $30 \mathrm{~s}$ centrifugation at $16100 \mathrm{~g}$, the supernatants were directly used in the ELISA test. The colour reaction was evaluated at $450 \mathrm{~nm}$ using the FLUOstar Optima microplate reader from BMG LABTECH.

Phylogenetic and $\mathbf{G}+\mathbf{C}$-content analyses. All available sequences of cyr and aoa genes, as well as rpoC1 gene sequences from cyanobacterial strains of the genera Aphanizomenon, Anabaena, Cylindrospermopsis and Raphidiopsis were retrieved from GenBank. Alignments were created using the software program CLC DNA Workbench version 5.0.2 and checked manually. Identical sequences were removed and maximum-likelihood (ML) analyses were carried out using the software program RAxML version 7.0.4 (Stamatakis, 2006) on the University of Oslo Bioportal. Evolutionary models were determined using the software TREEFINDER (Jobb, 2008). One hundred bootstrap replicates were generated for each analysis.

Further, bacterial amidinotransferase gene sequences were obtained from GenBank using the non-redundant database and the BLASTP algorithm (Altschul et al., 1997). The amidinotransferase genes cyrA and aoaA from C. raciborskii AWT205 (EU140798) and Aph. ovalisporum ILC-146 (AF395828) were used as query sequences. The sequences were aligned using the multiple alignment program MAFFT with the E-INS-I option (Katoh \& Toh, 2008). The alignments were checked manually, identical sequences were removed and ML analyses were carried out as described above.

$\mathrm{G}+\mathrm{C}$-content analyses were carried out using the program Isochore from the European Molecular Biology Open Software Suite (Rice et al., 2000). The window size was set to 5000 and the shift to 500 .

\section{RESULTS}

\section{Identification of the CYN biosynthesis gene cluster of Aphanizomenon sp. $10 \mathrm{E} 6$}

The pyrosequencing approach generated 929136 shotgun and 229474 paired-end reads (with 275.2 million bases of raw data). The reads assembled into 35 scaffolds, 12 of which had a maximum coverage of 9 , the remaining 23 had a minimum coverage of 14 . The 12 low-coverage scaffolds are likely to stem from contaminating organisms (Nederbragt et al., 2010). The high-coverage scaffolds had an average coverage of 36 times and a cumulative length of $6.18 \mathrm{Mb}$. They contained 890 contigs with a GC-content of $0.38 \pm 0.03$. Raw and assembled datasets are available from the authors on request.
BLAST database comparisons identified three contigs with highly similar sequences to the cyrlaoa genes of $C$. raciborskii, Aphanizomenon sp. and Aph. ovalisporum (contigs 393-395), which were located next to each other on scaffold 7. The gaps between contigs 393-395 as well as the gaps to the neighbouring contigs were closed by PCR and Sanger sequencing. The resulting contig containing the cyr gene cluster had a length of $57112 \mathrm{bp}$, contained 25 ORFs and is available under the GenBank accession number GQ385961.

Comparisons of the cyr gene cluster of Aphanizomenon sp. strain 10E6 and the cyr gene cluster characterized from $C$. raciborskii strain AWT205 (Mihali et al., 2008) revealed that 11 ORFs identified in strain 10E6 were clear orthologues of genes $c y r A-K$ in strain AWT205 (Table 2). The sequence similarity of these 11 genes was between 95.0\% (cyrK) and $99.7 \%$ (cyrB) nucleotide identity (Table 2). No clear orthologues for the genes $c y r L-O$ were found in Aphanizomenon sp. strain 10E6. In AWT205, cyrL and cyrM encode transposases, cyrN encodes an adenylylsulphate kinase, which is putatively involved in tailoring reactions resulting in the sulphation of $\mathrm{CYN}$, and $c y r O$ encodes a putative regulator (Mihali et al., 2008). In strain $10 \mathrm{E} 6$, orf3 codes for a transposase and vestiges of a transposase are present between $c y r H$ and $c y r K$. Orf4 is a short ORF with high similarity to an adenylylsulphate kinase from the cyanobacterium Trichodesmium erythraeum IMS101, and orf12 encodes a putative transcriptional attenuator. All three ORFs are found in the flanking region of the cyr gene cluster in Aphanizomenon sp. 10E6 (Table 3). Whether orf4 and orf12 are functional and involved in CYN synthesis and regulation remains to be experimentally investigated.

\section{cyr gene cluster organization}

The cyr gene clusters of the C. raciborskii strains AWT205 and CS-505 show perfect synteny (Stucken et al., 2010) and $>99.9 \%$ nucleotide identity (22 bp difference; 42164 bp alignment). The most notable difference between these gene clusters, the partial aoa gene cluster of Aph. ovalisporum strain ILC-146 and the cyr gene cluster of Aphanizomenon sp. strain 10E6, is the gene arrangement (Fig. 1). In the C. raciborskii strains, $c y r A-J$ are transcribed on the direct strand and $c y r K$ on the reverse strand. In Aphanizomenon sp. 10E6, cyrA, B, E and $K$ are transcribed on the direct strand, and $c y r C, D$ and $F-J$ are transcribed on the reverse strand. It appears as if the cyr gene cluster has been rearranged in three blocks: the first block contains cyrA, $B$ and $E$, and is located on the direct strands in $C$. raciborskii and Aphanizomenon sp. The second block corresponds to $c y r C$, which is situated downstream of cyrE and transcribed on the direct strand in C. raciborskii, but which is flipped around and located upstream of $c y r A$ in Aphanizomenon sp. 10E6. The third block involves cyrD$K$, which is (apart from $c y r K$ ) transcribed on the forward strand in C. raciborskii, but which is flipped around and 
Table 2. Comparisons between the cyr and aoa genes of C. raciborskii AWT205 (EU140798), Aph. ovalisporum ILC-146 (AF395828) and Aphanizomenon sp. 10E6 (GQ385961, present study)

NA, Not available.

\begin{tabular}{|c|c|c|c|c|c|c|c|c|}
\hline & \multirow{2}{*}{$\begin{array}{c}\mathrm{G}+\mathrm{C}- \\
\text { content } \\
10 \mathrm{E} 6\end{array}$} & \multicolumn{3}{|c|}{ Length (bp) } & \multicolumn{3}{|c|}{ Percentage identity (nucleotide) } & \multirow[t]{3}{*}{ Putative function $^{\star}$} \\
\hline & & AWT205 & $10 \mathrm{E} 6$ & ILC-164 & AWT205/ 10E6 & 10E6/ILC-146 & $\begin{array}{l}\text { AWT205/ } \\
\text { ILC-146 }\end{array}$ & \\
\hline 16S rDNA: & & 1447 & 1239 & 1165 & 95.0 & 94.6 & 93.9 & \\
\hline cyrA/aoaA & 0.47 & 1176 & 1176 & 1179 & 99.3 & 96.1 & 96.0 & Amidinotransferase \\
\hline cyrC/aoaC & 0.47 & 5004 & 5004 & $4299 \dagger$ & 99.5 & 97.3 & 97.2 & PKS KS-AT-KR-ACP \\
\hline$c y r D$ & 0.47 & 5631 & 5556 & NA & 98.2 & NA & NA & PKS KS-AT-DH-KR-ACP \\
\hline cyrE & 0.46 & 5667 & 5667 & NA & 99.6 & NA & NA & PKS KS-AT-DH-KR-ACP \\
\hline$c y r F$ & 0.47 & 4074 & 4074 & NA & 98.4 & NA & NA & PKS KS-AT-ACP \\
\hline cyrG & 0.48 & 1437 & 1437 & NA & 96.2 & NA & NA & Uracil ring formation \\
\hline
\end{tabular}

${ }^{*}$ According to Mihali et al. (2008).

$\dagger$ Partial gene sequence.

transcribed on the reverse strand (apart from $c y r K$ ) in Aphanizomenon sp. 10E6 (Fig. 1). The gene arrangement of the partial cyr gene clusters generated from the Aphanizomenon sp. strains 10E9 and 22D11 (GenBank accession GQ385959 and GQ385960) is the same as observed for Aphanizomenon sp. 10E6. The nucleotide sequences for the $c y r A$ gene (1176 bp) and the partial $c y r B$ (996 bp) and cyrC (4182 bp) genes were, apart from a single bp difference in strain 22D11, identical in all three Aphanizomenon sp. strains. No PCR products were amplified for the non-CYN-producing Aphanizomenon sp. strain 14E6.

The arrangement of the partial aoa gene cluster from Aph. ovalisporum strain ILC-146 was the same as the cyr genes in the other Aphanizomenon strains (Fig. 1). The sequence

Table 3. Best BLASTX hits for the putative ORFs flanking the cyr gene cluster in Aphanizomenon sp. $10 \mathrm{E} 6$

There were no hits for ORFs 6 (399 bp), 8 (360 bp) and 9 (348 bp).

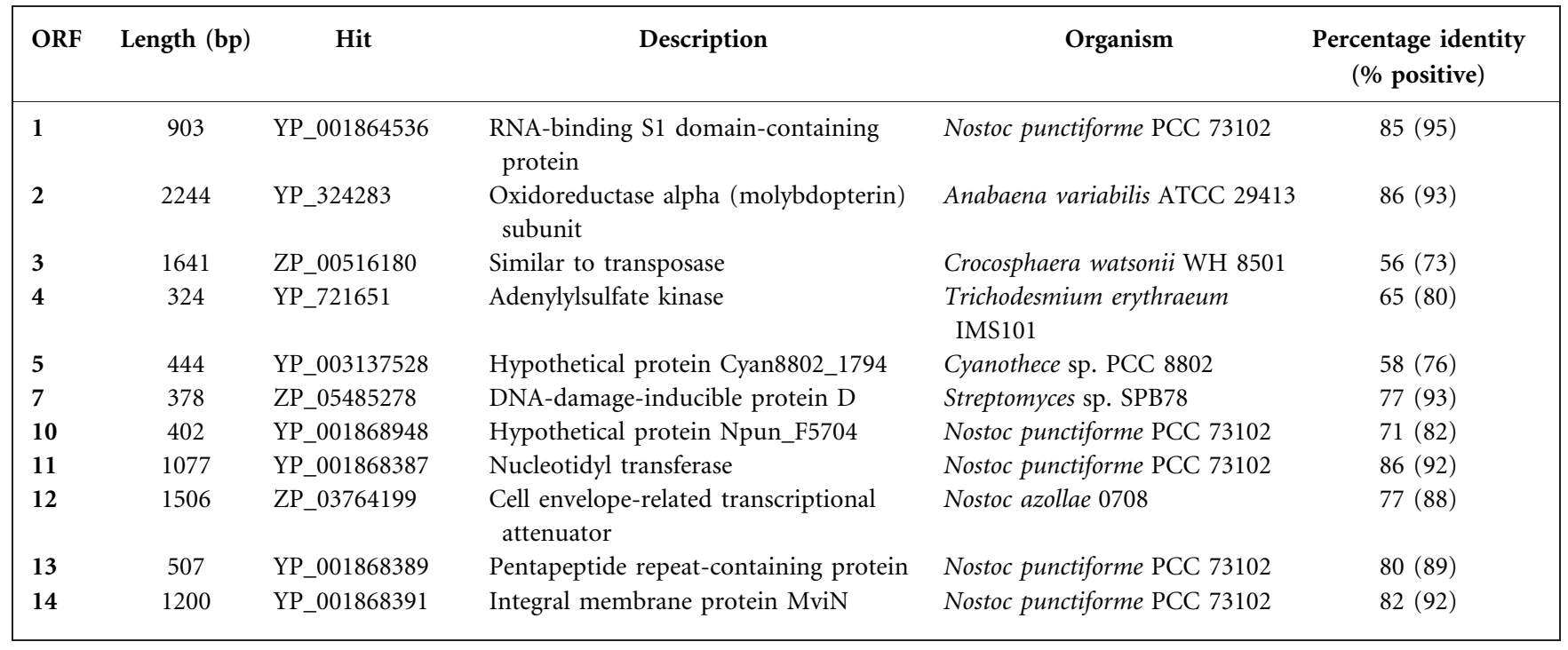




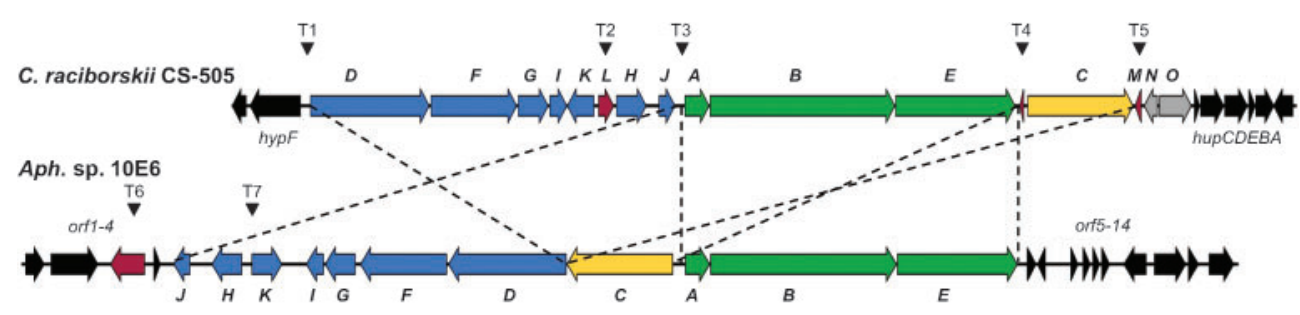

Aph. ovalisporum ILC-146

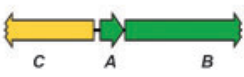

Fig. 1. Comparison between the cyr gene clusters of C. raciborskii CS-505 and Aphanizomenon sp. $10 \mathrm{E} 6$ and the partial aoa gene cluster of Aph. ovalisporum ILC-146. Black, flanking genes; blue, green and yellow, blocks of cyr genes that have been rearranged (see text); grey, cyr genes without clear homologues in strain 10E6; red, transposases; black triangles with numbers, regions containing transposases or vestiges thereof (see text and Table 4).

similarities between aoa and cyr genes were slightly less between Aph. ovalisporum and Aphanizomenon sp. compared with Aphanizomenon sp. and C. raciborskii (Table 2).

\section{CYN synthesis and presence of cyr genes}

None of the 18 Cylindrospermopsis and Aphanizomenon strains tested showed cross-reactivity with the CYN-ELISA, nor were any $c y r A$ or $c y r B$ fragments amplified from these strains (Table 1). The cyrA fragment was amplified for the CYN-producing Aphanizomenon sp. strains 10E6, 10E9 and 22D11, but not for the non-CYN-producing strains 06D11, 14E6 and 16D11 (Table 1).

Table 1 lists 226 cyanobacterial strains for which both CYN synthesis and the presence of cyr/aoa genes (or fragments thereof) have been investigated. Nine different genera are listed: Anabaena (38 strains), Anabaenopsis (2 strains), Aphanizomenon (90 strains), Cylindrospermopsis (89 strains), Microcystis (2 strains), Nodularia (2 strains), Limnothrix (1 strain), Raphidiopsis (1 strain) and Umezakia (1 strain). Of these, 35 strains have been reported to produce CYN; no CYN was detected in the remaining strains. Fragments of $c y r B$ and, if investigated, also of $c y r A$, were amplified in all of the CYN-positive strains. Neither of the fragments was amplified in the majority of CYN-negative strains. However, five CYN-negative strains contained $c y r$ gene fragments: one A. bergii, one Aphanizomenon issatschenkoi and three $C$. raciborskii (Table 1 ).

\section{Phylogenetic analyses}

Phylogenetic analysis of amidinotransferase genes showed that the amidinotransferases involved in CYN synthesis form a well-supported cluster (Fig. 2a). When only the amidinotransferase genes involved in CYN synthesis are analysed, i.e. aoaA and $c y r A$, they predominantly cluster according to their taxonomic classification (Fig. 2b). Exceptions are Aph. issatschenkoi CAWBG02 and U. natans TAC101; the former clusters with $C$. raciborskii and the latter with Aph. ovalisporum. Only single aoaA sequences of
Aph. issatschenkoi and $U$. natans are publicly available and the aoaA sequence of Aph. issatschenkoi is the shortest aoaA sequence available. When it is removed from the analysis, the alignment length increases from 608 to $1001 \mathrm{bp}$. As a result, the bootstrap values increase, but the topology of the tree does not change (data not shown). Only a few nucleotide sequences of $c y r B(a o a B)$ and $c y r C(a \circ a C)$ gene fragments were publicly available. Many of these sequences are short, highly similar or identical and/or did not overlap (Supplementary Tables S3 and S4), rendering comprehensive phylogenetic analyses impossible. Preliminary results are shown in Supplementary Figs S1 and S2, and indicate a similar pattern to that observed for $c y r A$.

The rpoC1 phylogeny (Fig. 2c) has a similar topology to the cyrA phylogeny: Aphanizomenon sp., Aph. ovalisporum and C. raciborskii form separate clusters. However, the distances are greater.

\section{Additional sequence features: transposases, flanking regions and $\mathrm{G}+\mathrm{C}$-content}

One putative transposase protein, denoted orf3, was identified adjacent to the cyr gene cluster of Aphanizomenon sp. 10E6. Further, remnants of a transposase were found between $\mathrm{cyrH}$ and $c y r K$. Of this $445 \mathrm{bp}$ long intergenic spacer (IGS), $145 \mathrm{bp}$ was identical to the sequence upstream of $c y r H$ in $C$. raciborskii, including 46 bp at the $3^{\prime}$ end of cyrL (Fig. 1, Table 4). In addition to the four transposases and vestiges thereof identified in the two C. raciborskii strains (Mihali et al., 2008; Stucken et al., 2010), we found further remnants of a transposase upstream of $c y r D$ in both $C$. raciborskii strains. These transposase vestiges had a high similarity to the transposase cyrM (denoted gene CRC_01707 in CS-505; Fig. 1, Table 4). No transposases or remnants thereof were found in the partial aoa gene cluster of Aph. ovalisporum strain ILC-146.

The genes flanking the cyr gene cluster in Aphanizomenon sp. 10E6 are different to the hyp/hup genes flanking the cyr gene cluster in C. raciborskii AWT205 and CS-505 (Fig. 1, 

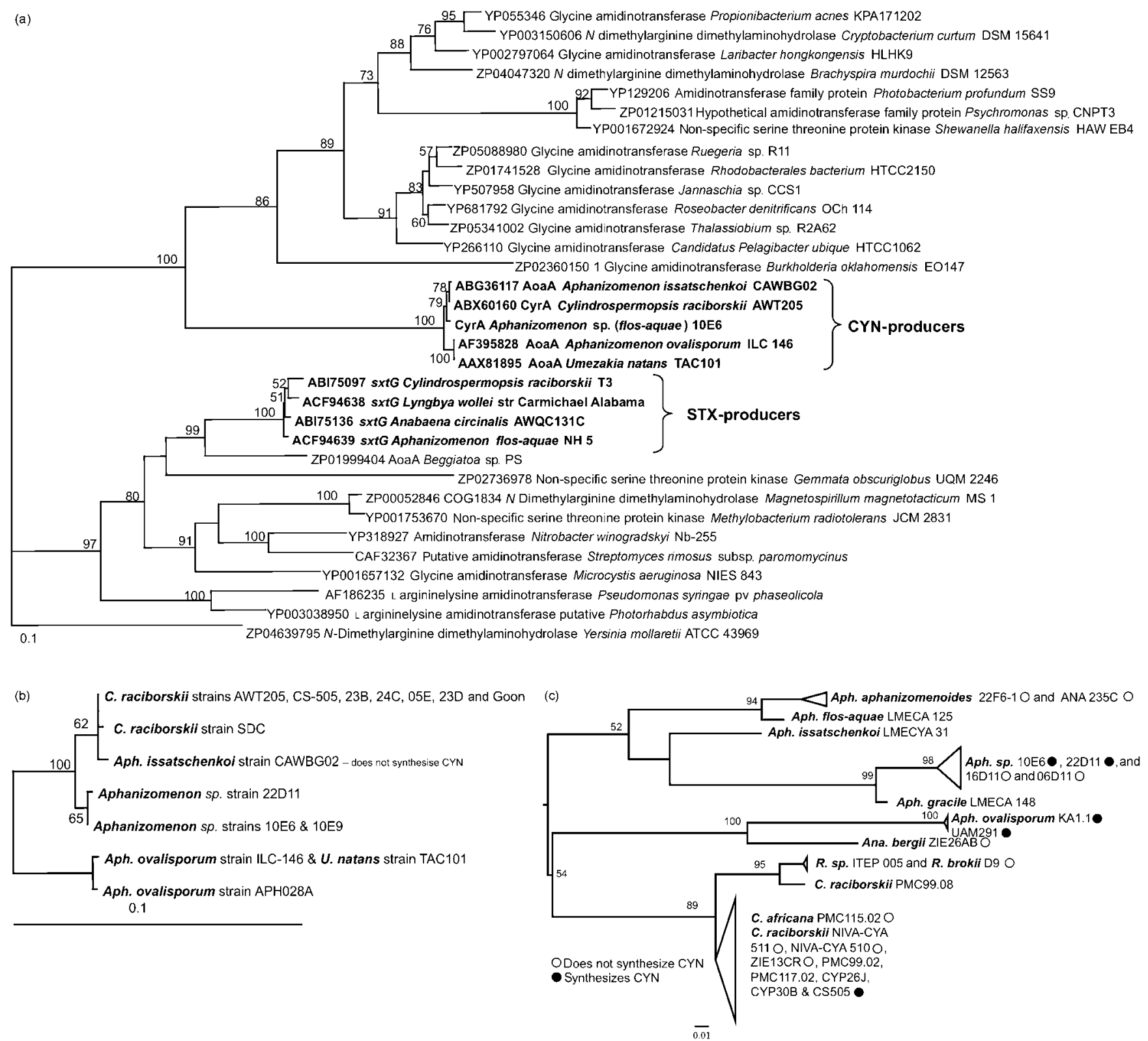

Fig. 2. Maximum-likelihood analyses of (a) bacterial amidinotransferases (amino acid alignment), (b) all available cyr $A$ and aoa $A$ genes (nucleotide alignment) and (c) rpoC1 sequences. GenBank accession numbers of strains in (b) and (c) are listed in Supplementary Tables S5 and S6.

Table 2) (Mihali et al., 2008; Stucken et al., 2010). The hyp genes in Aphanizomenon sp. 10E6 were located on contig 53, which mapped to scaffold 1, whereas the cyr genes were located on scaffold 7 (see above). The gene order was the same as in R. brookii D9, but no putative insertion site or ORF was found between $h y p F$ and hypC. Instead, an ORF was present between hypD and hypE (Fig. 3).

Apart from cyrI, all cyr genes of Aphanizomenon sp. 10E6 have a G+C-content $>0.44$ (Table 2). Analysis of scaffold 7 showed that the cyr genes are located in an area of unusually high $\mathrm{G}+\mathrm{C}$-content compared with the rest of the scaffold (Fig. 4). The same area of high $\mathrm{G}+\mathrm{C}$-content was observed on the $C$. raciborskii CS-505 contig 27, which contains the cyr genes. No region of high $\mathrm{G}+\mathrm{C}$-content was present surrounding or within the region encoding the hyp/ hup gene cluster of $R$. brookii D9 (Fig. 4).

\section{DISCUSSION}

Our results show that the genes involved in CYN synthesis are highly conserved not only between strains of the same species but also between strains of different genera. Gene 
Table 4. Transposase regions in the cyr gene clusters of C. raciborskii and Aphanizomenon sp. strains See Fig. 1 for position in the gene clusters.

\begin{tabular}{|c|c|c|c|c|c|c|c|}
\hline & Region/gene & Strain & BLASTX hit & Description & Organism & $\begin{array}{l}\text { Hit length } \\
\text { (aa) }\end{array}$ & $\begin{array}{l}\text { Percentage identity } \\
\text { (\% positive) }\end{array}$ \\
\hline T1 & hypF-cyrD & AWT205, CS-505 & ZP_06307802 & $\begin{array}{l}\text { Transposase } \\
\text { protein }\end{array}$ & $\begin{array}{l}\text { Cylindrospermopsis raciborskii } \\
\text { CS-505 }\end{array}$ & 71 & $93(93)$ \\
\hline $\mathrm{T} 2$ & cyrL & AWT205, CS-505 & YP_002478395 & $\begin{array}{c}\text { Transposase, IS4 } \\
\text { family protein }\end{array}$ & Cyanothece sp. PCC 7425 & 214 & $69(79)$ \\
\hline T3 & cyrJ-cyrA & AWT205, CS-505 & ZP_06308708 & Transposase & $\begin{array}{l}\text { Cylindrospermopsis raciborskii } \\
\text { CS-505 }\end{array}$ & 76 & $92(95)$ \\
\hline T4 & cyrE-cyrC & AWT205, CS-505 & ZP_06307257 & Transposase & $\begin{array}{l}\text { Cylindrospermopsis raciborskii } \\
\text { CS-505 }\end{array}$ & 33 & $91(94)$ \\
\hline T5 & $c y r M$ & AWT205, CS-505 & ZP_06307810 & $\begin{array}{l}\text { Transposase IS5 } \\
\text { family protein }\end{array}$ & $\begin{array}{l}\text { Cylindrospermopsis raciborskii } \\
\text { CS-505 }\end{array}$ & 79 & $96(97)$ \\
\hline T6 & ORF3 & $10 \mathrm{E} 6$ & ZP_00516180 & Similar to transposase & Crocosphaera watsonii WH 8501 & 537 & $56(73)$ \\
\hline T7 & cyrH-cyrK & 10E6 & ACG63861 & ProF, transposase & Planktothrix rubescens & 33 & $67(79)$ \\
\hline
\end{tabular}

synteny and nucleotide sequence are almost identical between two C. raciborskii strains (Stucken et al., 2010), and in the present study, we found the same degree of conservation between the CYN genes of Aphanizomenon sp. 10E6 and the two partial cyr gene clusters of Aphanizomenon sp. strains $10 \mathrm{E} 9$ and 22D11. The synteny between the $C$. raciborskii and Aphanizomenon sp. cyr gene clusters differed (Fig. 1) but the nucleotide sequence conservation for all orthologous genes was greater than $95 \%$. Thus, it was in the range of, or higher than, the similarity of the 16S rRNA genes of the two species (Table 2).

(a)

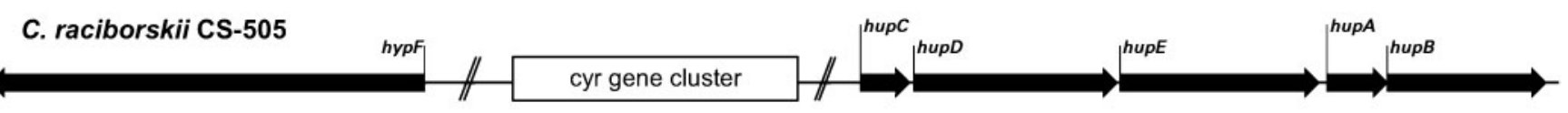

\section{R. brookii D9}

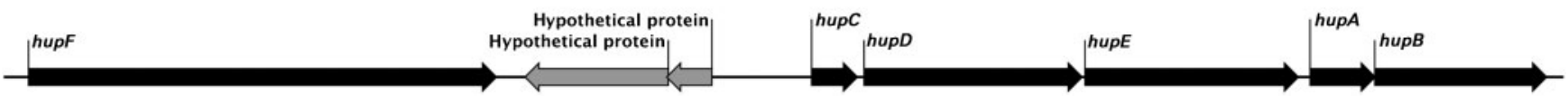

Aph. sp. $10 \mathrm{E} 6$

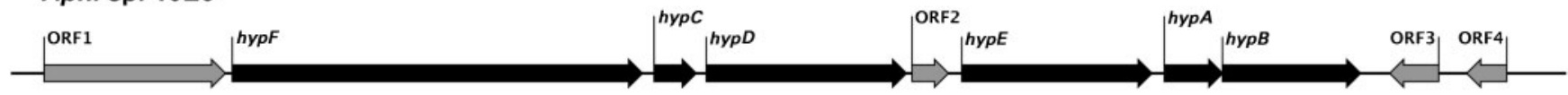

(b)

\begin{tabular}{|c|c|c|c|c|}
\hline & Hit & Description & Hit length & Percent identity (\% positive) \\
\hline hypA & ZP_03766297 & Hydrogenase nickel insertion protein HypA ['Nostoc azollae' 0708] & 98 & $87(94)$ \\
\hline hypB & ZP_03766298 & Hydrogenase accessory protein HypB ['Nostoc azollae' 0708] & 261 & $85(92)$ \\
\hline hypD & ZP_03766295 & Hydrogenase expression/formation protein HypD ['Nostoc azollae' 0708] & 382 & $89(95)$ \\
\hline hypE & ZP_03766296 & Hydrogenase expression/formation protein HypE ['Nostoc azollae' 0708] & 359 & $87(95)$ \\
\hline hypF & NP_484737 & Hydrogenase maturation protein [Nostoc sp. PCC 7120] & 785 & $72(84)$ \\
\hline ORF1 & NP_484736 & Hypothetical protein alr0693 [Nostoc sp. PCC 7120] & 347 & $81(90)$ \\
\hline ORF2 & YP_325097 & 4-Oxalocrotonate tautomerase [Anabaena variabilis ATCC 29413] & 52 & $81(94)$ \\
\hline
\end{tabular}

Fig. 3. hyp gene cluster of Aphanizomenon sp. $10 \mathrm{E} 6$ and flanking genes. (a) Arrangement of the cluster. (b) Best BLASTX hits. There were no hits for ORF3 and ORF4. 
C. raciborskii CS-505 ACYA01000027

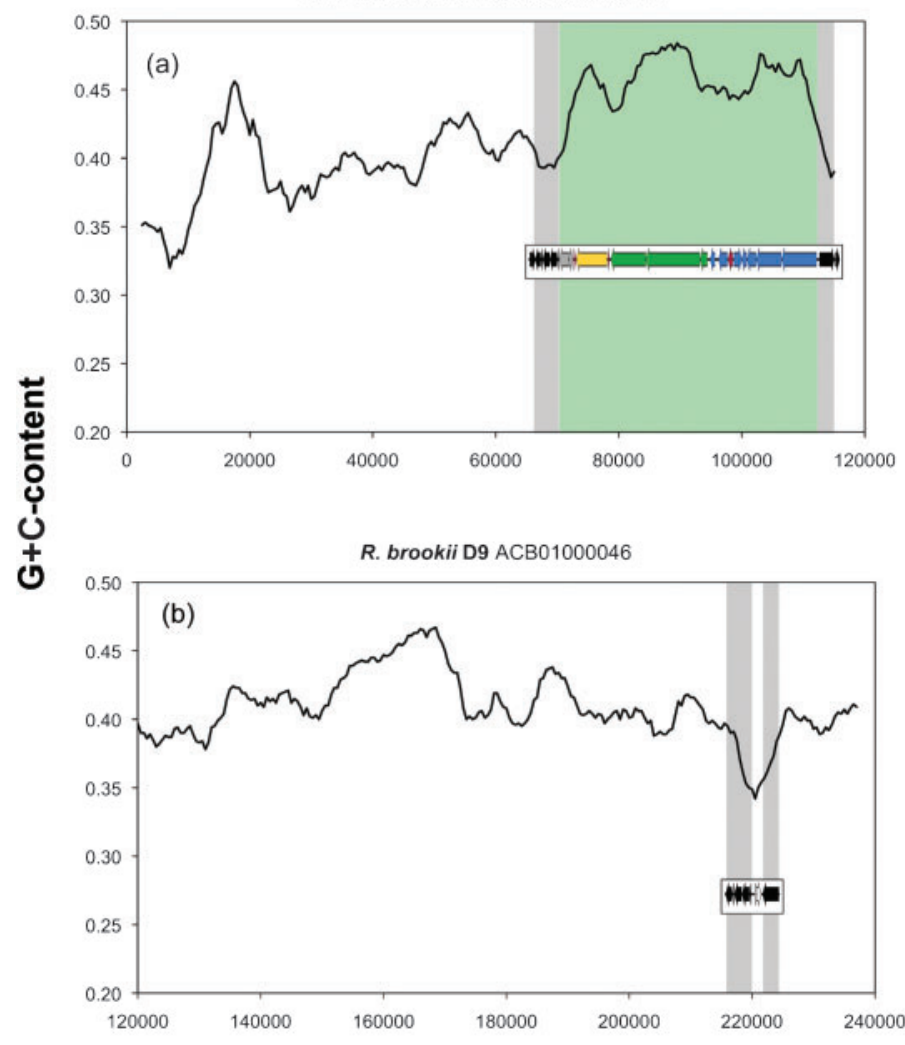

Aphanizomenon sp. 10E6 scaffold00007

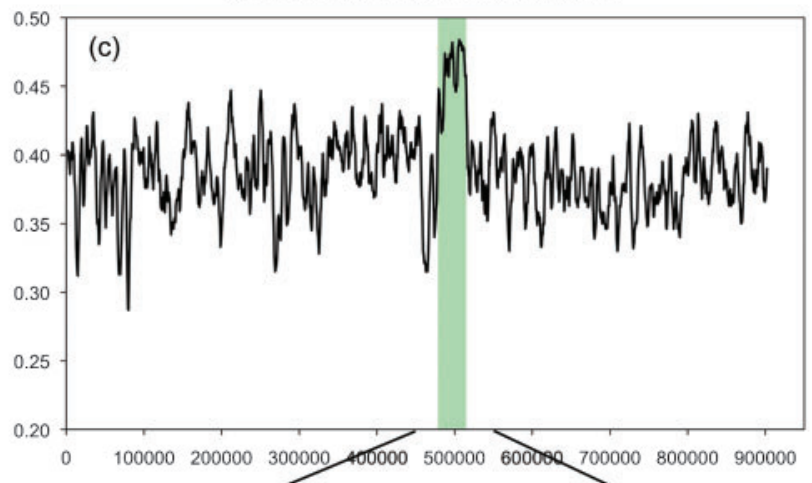

Position on contig or scaffold

Fig. 4. $\mathrm{G}+\mathrm{C}$ isochors overlaid with cyr gene clusters and their flanking regions (as shown in Fig. 1). Green shading, cyr genes; grey shading, hyp/hup gene clusters. (a) Contig 27 of C. raciborskii CS-505 (ACYA01000027). (b) Contig 46 of R. brookii D9, partial sequence (ACYB01000046). (c) Scaffold 7 of Aphanizomenon sp. 10E6, gaps removed.

Cyanobacterial toxins are frequently produced by strains of different genera; however, the conservation of genes is usually considerably less than that observed for the CYN genes. Microcystin, for example, is produced by cyanobacteria of the genera Microcystis, Anabaena and Planktothrix. The nucleotide sequence of the different $m c y$ genes has been shown to vary between 67 and $81 \%$ (Rouhiainen et al., 2004). Similarly, saxitoxin is produced by several genera of freshwater cyanobacteria and comparisons between the sxt genes of Aphanizomenon, Anabaena and Cylindrospermopsis revealed a 53-99\% nucleotide identity of the different orthologous genes (Mihali et al., 2009).

Our phylogenetic analyses showed that the amidinotransferases involved in CYN synthesis are more conserved across different cyanobacterial genera than amidinotransferases of the same genera involved in the synthesis of different cyanotoxins (see Fig. 2a). These results are in line with the high sequence conservation observed. When the CYN gene sequences were analysed alone, they clustered according to their taxonomic affiliation (see Fig. $2 \mathrm{~b}$ and Supplementary Fig. S1). The tree topology was similar to that observed for rpoC1 (see Fig. 2c) except the distances were considerably shorter. In essence, three clusters emerged: one containing all the Aphanizomenon sp. strains, the second containing strains of the genera Cylindrospermopsis and Raphidiopsis and the third containing Aph. ovalisporum, A. bergii and U. natans. The same pattern was also observed for other genes, such as the $16 \mathrm{~S}$ rDNA gene and $c p c B A$-IGS (e.g. Stüken et al., 2009). The only sequences found to contradict this pattern were partial cyrlaoa sequences derived from strains which do not produce CYN (Fig. 2b and Supplementary Fig. S1).

The presence of transposases and vestiges thereof coupled with the different arrangement of genes in the C. raciborskii and Aphanizomenon sp. cyr gene clusters indicate past recombination events within these clusters. The mcy and sxt gene clusters show similar signs of reorganization. For the mcy genes, it has been shown that the operon structure and the order of genes varies between the genera Planktothrix, Anabaena and Microcystis (reviewed by Dittmann \& Börner, 2005). In addition, recombination between different domains within the mcy gene clusters, point mutations and deletion of gene regions, as well as lack of substrate specificity of A-domains have been shown to contribute to the synthesis of different microcystin 
isoforms (Fewer et al., 2008; Mikalsen et al., 2003; Tooming-Klunderud et al., 2008). A deletion within the second module of $m c y A$ and the first module of $m c y B$ resulted in the synthesis of another cyanotoxin, nodularin (Moffitt \& Neilan, 2004; Rantala et al., 2004). The number of genes within the sxt gene clusters of Aphanizomenon, Anabaena and Cylindrospermopsis varies, but five regions containing homologous sxt genes have been identified in all three genera. The arrangement of these five regions differs in each cluster, and the presence of transposases indicates a prevalent recombination (Mihali et al., 2009). The number, type and conservation of tailoring genes present in the $s x t$ gene clusters are thought to determine which saxitoxin analogues are produced. It has been shown that the sxtI gene, which encodes an O-carbamoyltransferase, is truncated in a Lynbya wollei strain. As a result, this strain only produces decarbamoylated analogues of saxitoxin (Kellmann et al., 2008). In contrast with microcystin and saxitoxin, for which numerous chemical variants have been described (e.g. Schantz, 1986; Welker \& von Döhren, 2006), only two analogues of cylindrospermopsin are known: 7-epi-CYN and deoxy-CYN (Banker et al., 2000; Norris et al., 1999). The genetic basis of these CYN variants is not known, but it is likely that the dearth of analogues is related to the high sequence conservation.

The cyr gene clusters in C. raciborskii strains AWT205 and CS-505 are flanked by genes of the hydrogenase gene cluster (Mihali et al., 2008; Stucken et al., 2010). This hyp/ hup gene cluster is present in the Aphanizomenon sp. 10E6 genome (Fig. 3) but is not in close proximity to the cyr genes. Instead, the cyr genes are flanked by a transposase and an oxidoreductase protein on one side and a series of short ORFs with unknown function on the other side (Fig. 1 and Table 3). G+C-content analysis showed that the genomic region containing the cyr genes had an atypically high $\mathrm{G}+\mathrm{C}$-content compared with the rest of the scaffold (Fig. 4c) and also compared with the average genomic $\mathrm{G}+\mathrm{C}$-content. A similar high $\mathrm{G}+\mathrm{C}$-content region which contains the $c y r$ genes was observed for $C$. raciborskii CS-505 (Fig. 4a). In contrast, no such region of high $\mathrm{G}+\mathrm{C}$-content was observed between the hyp/hup genes in $R$. brookii D9 (Fig. 4b), an area that has been proposed to contain the insertion or deletion site of the cyr genes in C. raciborskii CS-505 and R.brookii D9 (Stucken et al., 2010).

Horizontal gene transfers (HGTs) play a prominent role in shaping cyanobacterial genomes (e.g. Zhaxybayeva et al., 2006) and it has been suggested that the cyr genes have been transferred between closely related strains (Stucken et al., 2009) as well as between strains of different genera (Kellmann et al., 2006). The atypically high G+C-content of the cyr genes, their high sequence conservation, the presence of transposases and vestiges thereof within and at the sides of the cyr gene clusters, and the differences in flanking genes in Aphanizomenon sp. compared with $C$. raciborskii, support the view that the cyr genes have been transferred by HGT. In addition, the incongruent phylogeny of the cyr gene fragments from non-CYNproducing strains corroborates this view. Since the entire gene sequences and flanking regions of these fragments are not available, it can only be speculated that they represent signs of HGT events. In this light, it would also be valuable to sequence the aoa gene fragments and flanking regions found in three non-CYN -producing strains, which are thought to represent natural deletion mutants (Rasmussen et al., 2008).

The only results that may contradict HGT come from the phylogenetic analyses of cyr/aoa sequences from CYNproducing strains. These sequences cluster similarly to ribosomal and housekeeping genes, possibly indicating that the genes are ancient and have co-evolved. Such coevolution has been suggested for genes involved in microcystin and nodularin biosynthesis (Rantala et al., 2004). However, the sequence divergences of rpoC1, 16S rRNA and $m c y$ genes were found to be approximately the same in microcystin producing strains (Rantala et al., 2004), whereas the cyr genes described here are more conserved than 16S rRNA and rpoC1 genes of the same strains (Table 2 and Supplementary Tables S3-S6).

In summary, two main scenarios may explain the current distribution and organization of the CYN gene clusters. The first involves an ancient origin of the CYN genes and implies that they were present in a common ancestor of all CYN-producing genera. The current distribution of CYNproducing and -non-producing strains within the same species is due to gene loss in the non-producing species. The high sequence conservation of the CYN genes may be a result of strong functional constrains and selection mechanisms. In the second scenario, which we favour, the high sequence conservation may also be caused by functional constraints and purifying selection. But in addition, HGT events are likely to have played a prominent role in spreading the CYN genes. The presence of gene fragments in non-CYN-producing strains with contrasting phylogenetic signals suggests that at least parts of the cluster have been transferred. Single transfers of the entire gene cluster into new genera may explain the phylogeny and distribution of CYN genes in CYN-producing taxa. The direction of transfer and the source of the CYN gene cluster remain obscure.

So far, CYN-producing strains of the Aphanizomenon sp. group have only been isolated from German waters. Evidence is accumulating, however, to show that strains belonging to this species also synthesize CYN elsewhere. The toxin has been reported in freshwater bodies in Italy (Messineo et al., 2009), the Czech Republic (Bláhová et al., 2009), Poland (Kokocinski et al., 2009) and France (Brient et al., 2009), which contained Aph. flos-aquae, Aph. gracile or morphologically related species. Further sampling and isolation of strains from these different locations and the analysis of their cyr gene clusters and flanking regions will greatly improve our understanding of the evolution of this gene cluster. 


\section{ACKNOWLEGEMENTS}

We would like to thank Ave Tooming-Klunderud at the Ultra HighThroughput Sequencing Platform (UTSP), CEES, for technical assistance with 454 library preparation, amplification and pyrosequencing; 454 Life Sciences (Branford, Connecticut, USA) for $3 \mathrm{~kb}$ paired-end sequencing; Thomas Rohrlack for confirming CYN production in the German Aphanizomenon sp. strains with LC-MS/ MS and the provision of the 18 NIVA-CYA strains; Karina Preußel for the provision of six German Aphanizomenon sp. strains; Alexander J. Nederbragt and Karin Lagesen for guidance in and help with bioinformatic analyses; Helene M. Svendsen for assistance with laboratory work. This work was supported by a Marie Curie stipend to A.S. and a grant from the Norwegian Research Council to K.S. J.

\section{REFERENCES}

Altschul, S. F., Madden, T. L., Schaffer, A. A., Zhang, J. H., Zhang, Z., Miller, W. \& Lipman, D. J. (1997). Gapped BLAST and PSI-BLAST: a new generation of protein database search programs. Nucleic Acids Res 25, 3389-3402.

Ballot, A., Fastner, J. \& Wiedner, C. (2010). Paralytic shellfish poisoning toxin-producing cyanobacterium Aphanizomenon gracile in northeast Germany. Appl Environ Microbiol 76, 1173-1180.

Banker, R., Carmeli, S., Hadas, O., Teltsch, B., Porat, R. \& Sukenik, A. (1997). Identification of cylindrospermopsin in Aphanizomenon ovalisporum (Cyanophyceae) isolated from Lake Kinneret, Israel. J Phycol 33, 613-616.

Banker, R., Teltsch, B., Sukenik, A. \& Carmeli, S. (2000). 7Epicylindrospermopsin, a toxic minor metabolite of the cyanobacterium Aphanizomenon ovalisporum from Lake Kinneret, Israel. J Nat Prod 63, 387-389.

Berger, C., Ba, N., Gugger, M., Bouvy, M., Rusconi, F., Couté, A., Troussellier, M. \& Bernard, C. (2006). Seasonal dynamics and toxicity of Cylindrospermopsis raciborskii in Lake Guiers (Senegal, West Africa). FEMS Microbiol Ecol 57, 355-366.

Bernard, C., Harvey, M., Briand, J. F., Bire, R., Krys, S. \& Fontaine, J. J. (2003). Toxicological comparison of diverse Cylindrospermopsis raciborskii strains: evidence of liver damage caused by a French $C$. raciborskii strain. Environ Toxicol 18, 176-186.

Bernard, C., Froscio, S., Campbell, R., Monis, P., Humpage, A. \& Fabbro, L. (2009). Novel toxic effects associated with a tropical Limnothrix/Geitlerinema-like cyanobacterium. Environ Toxicol (in press). doi:10.1002/tox.20552.

Berry, J. P. \& Lind, O. (2009). First evidence of "paralytic shellfish toxins" and cylindrospermopsin in a Mexican freshwater system, Lago Catemaco, and apparent bioaccumulation of the toxins in "tegogolo" snails (Pomacea patula catemacensis). Toxicon 55, 930-938.

Bláhová, L., Babica, P., Adamovský, O., Kohoutek, J., Maršálek, B. \& Bláha, L. (2008). Analyses of cyanobacterial toxins (microcystins, cylindrospermopsin) in the reservoirs of the Czech Republic and evaluation of health risks. Environ Chem Lett 6, 223-227.

Bláhová, L., Oravec, M., Maršálek, B., Šejnohová, L., Šimek, Z. \& Bláha, L. (2009). The first occurrence of the cyanobacterial alkaloid toxin cylindrospermopsin in the Czech Republic as determined by immunochemical and LC/MS methods. Toxicon 53, 519-524.

Bourke, A. T. C., Hawes, R. B., Neilson, A. \& Stallman, D. (1983). An outbreak of hepato-enteritis (the Palm Island mystery disease) possibly caused by algal intoxication. Toxicon 21, 4 .

Brient, L., Lengronne, M., Bormans, M. \& Fastner, J. (2009). First occurrence of cylindrospermopsin in freshwater in France. Environ Toxicol 24, 415-420.
Burgoyne, D. L., Hemscheidt, T. K., Moore, R. E. \& Runnegar, M. T. C. (2000). Biosynthesis of cylindrospermopsin. J Org Chem 65, 152-156.

Burns, J., Williams, C. \& Chapman, A. (2002). Cyanobacteria and their toxins in Florida surface waters. In Abstracts of the meeting Health Effects of Exposure to Cyanobacteria Toxins: State of the Science August 2002, pp. 16-21. Edited by D. Johnson \& R. D. Harbison. Saratoga, FL.

Carmichael, W. W., Azevedo, S., An, J. S., Molica, R. J. R., Jochimsen, E. M., Lau, S., Rinehart, K. L., Shaw, G. R. \& Eaglesham, G. K. (2001). Human fatalities from cyanobacteria: chemical and biological evidence for cyanotoxins. Environ Health Perspect 109, 663-668.

Chonudomkul, D., Yongmanitchai, W., Theeragool, G., Kawachi, M., Kasai, F., Kaya, K. \& Watanabe, M. M. (2004). Morphology, genetic diversity, temperature tolerance and toxicity of Cylindrospermopsis raciborskii (Nostocales, Cyanobacteria) strains from Thailand and Japan. FEMS Microbiol Ecol 48, 345-355.

Dittmann, E. \& Börner, T. (2005). Genetic contributions to the risk assessment of microcystin in the environment. Toxicol Appl Pharmacol 203, 192-200.

Fastner, J., Heinze, R., Humpage, A. R., Mischke, U., Eaglesham, G. K. \& Chorus, I. (2003). Cylindrospermopsin occurrence in two German lakes and preliminary assessment of toxicity and toxin production of Cylindrospermopsis raciborskii (Cyanobacteria) isolates. Toxicon 42, 313-321.

Fastner, J., Rücker, J., Stüken, A., Preußel, K., Nixdorf, B., Chorus, I., Köhler, A. \& Wiedner, C. (2007). Occurrence of the cyanobacterial toxin cylindrospermopsin in northeast Germany. Environ Toxicol 22, 26-32.

Fergusson, K. M. \& Saint, C. P. (2003). Multiplex PCR assay for Cylindrospermopsis raciborskii and cylindrospermopsin-producing cyanobacteria. Environ Toxicol 18, 120-125.

Fewer, D. P., Tooming-Klunderud, A., Jokela, J., Wahsten, M., Rouhiainen, L., Kristensen, T., Rohrlack, T., Jakobsen, K. S. \& Sivonen, K. (2008). Natural occurrence of microcystin synthetase deletion mutants capable of producing microcystins in strains of the genus Anabaena (Cyanobacteria). Microbiology 154, 1007-1014.

Haande, S., Rohrlack, T., Ballot, A., Roberg, K., Skulberg, R., Beck, M. \& Wiedner, C. (2008). Genetic characterisation of Cylindrospermopsis raciborskii (Nostocales, Cyanobacteria) isolates from Africa and Europe. Harmful Algae 7, 692-701.

Harada, K. I., Ohtani, I., Iwamoto, K., Suzuki, M., Watanabe, M. F., Watanabe, M. \& Terao, K. (1994). Isolation of cylindrospermopsin from a cyanobacterium Umezakia natans and its screening method. Toxicon 32, 73-84.

Hawkins, P. R., Chandrasena, N. R., Jones, G. J., Humpage, A. R. \& Falconer, I. R. (1997). Isolation and toxicity of Cylindrospermopsis raciborskii from an ornamental lake. Toxicon 35, 341-346.

Jobb, G. (2008). TREEFINDER version October 2008. Munich, Germany. Distributed by the author at http://www.treefinder.de.

Katoh, K. \& Toh, H. (2008). Recent developments in the MAFFT multiple sequence alignment program. Brief Bioinform 9, 286-298.

Kellmann, R., Mills, T. \& Neilan, B. A. (2006). Functional modeling and phylogenetic distribution of putative cylindrospermopsin biosynthesis enzymes. J Mol Evol 62, 267-280.

Kellmann, R., Mihali, T. K. \& Neilan, B. A. (2008). Identification of a saxitoxin biosynthesis gene with a history of frequent horizontal gene transfers. J Mol Evol 67, 526-538.

Kokocinski, M., Dziga, D., Spoof, L., Stefaniak, K., Jurczak, T., Mankiewicz-Boczek, J. \& Meriluoto, J. (2009). First report of the cyanobacterial toxin cylindrospermopsin in the shallow, eutrophic lakes of western Poland. Chemosphere 74, 669-675. 
Lagos, N., Onodera, H., Zagatto, P. A., Andrinolo, D., Azevedo, S. \& Oshima, Y. (1999). The first evidence of paralytic shellfish toxins in the freshwater cyanobacterium Cylindrospermopsis raciborskii, isolated from Brazil. Toxicon 37, 1359-1373.

Li, R., Carmichael, W. W., Brittain, S., Eaglesham, G. K., Shaw, G. R., Mahakhant, A., Noparatnaraporn, N., Yongmanitchai, W., Kaya, K. \& Watanabe, M. M. (2001a). Isolation and identification of the cyanotoxin cylindrospermopsin and deoxy-cylindrospermopsin from a Thailand strain of Cylindrospermopsis raciborskii (Cyanobacteria). Toxicon 39, 973-980.

Li, R. H., Carmichael, W. W., Brittain, S., Eaglesham, G. K., Shaw, G. R., Liu, Y. D. \& Watanabe, M. M. (2001b). First report of the cyanotoxins cylindrospermopsin and deoxycylindrospermopsin from Raphidiopsis curvata (Cyantobacteria). J Phycol 37, 1121-1126.

Messineo, V., Bogialli, S., Melchiorre, S., Sechi, N., Lugliè, A., Casiddu, P., Mariani, M. A., Padedda, B. M., Di Corcia, A. \& other authors (2009). Cyanobacterial toxins in Italian freshwaters. Limnologica 39, 95-106.

Mihali, T. K., Kellmann, R., Muenchhoff, J., Barrow, K. D. \& Neilan, B. A. (2008). Characterization of the gene cluster responsible for cylindrospermopsin biosynthesis. Appl Environ Microbiol 74, 716-722.

Mihali, T.K., Kellmann, R. \& Neilan, B. (2009). Characterisation of the paralytic shellfish toxin biosynthesis gene clusters in Anabaena circinalis AWQC131C and Aphanizomenon sp. NH-5. BMC Biochem 10,8 .

Mikalsen, B., Boison, G., Skulberg, O. M., Fastner, J., Davies, W., Gabrielsen, T. M., Rudi, K. \& Jakobsen, K. S. (2003). Natural variation in the microcystin synthetase operon mcyABC and impact on microcystin production in Microcystis strains. J Bacteriol 185, 2774-2785.

Moffitt, M. C. \& Neilan, B. A. (2004). Characterization of the nodularin synthetase gene cluster and proposed theory of the evolution of cyanobacterial hepatotoxins. Appl Environ Microbiol 70, 6353-6362.

Nederbragt, A. J., Rounge, T. B., Kausrud, K. L. \& Jakobsen, K. S. (2010). Identification and quantification of genomic repeats and sample contamination in assemblies of 454 pyrosequencing reads. Sequencing 782465. doi:10.1155/2010/782465.

Neilan, B. A., Saker, M. L., Fastner, J., Torokne, A. \& Burns, B. P. (2003). Phylogeography of the invasive cyanobacterium Cylindrospermopsis raciborskii. Mol Ecol 12, 133-140.

Norris, R. L., Eaglesham, G. K., Pierens, G., Shaw, G. R., Smith, M. J., Chiswell, R. K., Seawright, A. A. \& Moore, M. R. (1999). Deoxycylindrospermopsin, an analog of cylindrospermopsin from Cylindrospermopsis raciborskii. Environ Toxicol 14, 163-165.

Ohtani, I., Moore, R. E. \& Runnegar, M. T. C. (1992). Cylindrospermopsin - a potent hepatotoxin from the blue-green alga Cylindrospermosis raciborskii. J Am Chem Soc 114, 7941-7942.

Pollingher, U., Hadas, O., Yacobi, Y. Z., Zohary, T. \& Berman, T. (1998). Aphanizomenon ovalisporum (Forti) in Lake Kinneret, Israel. J Plankton Res 20, 1321-1339.

Preußel, K. (2007). Identification of cylindrospermopsin-producing cyanobacteria. In Cylindrospermopsis raciborskii and Cylindrospermopsin in the Lakes of the Berlin Area: Occurences, Causes and Consequences, pp. 41-47. Edited by C. Wiedner, J. Rücker \& B. Weigert. Berlin: Kompetenzzentrum Wasser Berlin. http://www.igb-berlin.de/abt3/ mitarbeiter/c.wiedner/englisch_cylindrospermopsis.pdf.

Preußel, K., Stüken, A., Wiedner, C., Chorus, I. \& Fastner, J. (2006). First report on cylindrospermopsin producing Aphanizomenon flosaquae (Cyanobacteria) isolated from two German lakes. Toxicon 47, 156-162.

Rantala, A., Fewer, D. P., Hisbergues, M., Rouhiainen, L., Vaitomaa, J., Borner, T. \& Sivonen, K. (2004). Phylogenetic evidence for the early evolution of microcystin synthesis. Proc Natl Acad Sci U S A 101, 568573.

Rasmussen, J. P., Giglio, S., Monis, P. T., Campbell, R. J. \& Saint, C. P. (2008). Development and field testing of a real-time PCR assay for cylindrospermopsin-producing cyanobacteria. J Appl Microbiol 104, 1503-1515.

Rice, P., Longden, I. \& Bleasby, A. (2000). EMBoss: the European Molecular Biology Open Software Suite. Trends Genet 16, 276277.

Rouhiainen, L., Vakkilainen, T., Siemer, B. L., Buikema, W., Haselkorn, R. \& Sivonen, K. (2004). Genes coding for hepatotoxic heptapeptides (microcystins) in the cyanobacterium Anabaena strain 90. Appl Environ Microbiol 70, 686-692.

Rücker, J., Stüken, A., Nixdorf, B., Fastner, J., Chorus, I. \& Wiedner, C. (2007). Concentrations of particulate and dissolved cylindrospermopsin in 21 Aphanizomenon-dominated temperate lakes. Toxicon 50, 800-809.

Saker, M. L. \& Griffiths, D. J. (2000). The effect of temperature on growth and cylindrospermopsin content of seven isolates of Cylindrospermopsis raciborskii (Nostocales, Cyanophyceae) from water bodies in northern Australia. Phycologia 39, 349-354.

Saker, M. L., Neilan, B. A. \& Griffiths, D. J. (1999). Two morphological forms of Cylindrospermopsis raciborskii (Cyanobacterta) isolated from Solomon Dam, Palm Island, Queensland. J Phycol 35, 599-606.

Saker, M. L., Nogueira, I. C. G., Vasconcelos, V. M., Neilan, B. A., Eaglesham, G. K. \& Pereira, P. (2003). First report and toxicological assessment of the cyanobacterium Cylindrospermopsis raciborskii from Portuguese freshwaters. Ecotoxicol Environ Saf 55, 243-250.

Schantz, E. J. (1986). Chemistry and biology of saxitoxin and related toxins. Ann N Y Acad Sci 479, 15-23.

Schembri, M. A., Neilan, B. A. \& Saint, C. P. (2001). Identification of genes implicated in toxin production in the cyanobacterium Cylindrospermopsis raciborskii. Environ Toxicol 16, 413-421.

Seifert, M., McGregor, G., Eaglesham, G., Wickramasinghe, W. \& Shaw, G. (2007). First evidence for the production of cylindrospermopsin and deoxy-cylindrospermopsin by the freshwater benthic cyanobacterium, Lyngbya wollei (Farlow ex Gornont) Speziale and Dyck. Harmful Algae 6, 73-80.

Shalev-Alon, G., Sukenik, A., Livnah, O., Schwarz, R. \& Kaplan, A. (2002). A novel gene encoding amidinotransferase in the cylindrospermopsin producing cyanobacterium Aphanizomenon ovalisporum. FEMS Microbiol Lett 209, 87-91.

Shaw, G. R., Sukenik, A., Livne, A., Chiswell, R. K., Smith, M. J., Seawright, A. A., Norris, R. L., Eaglesham, G. K. \& Moore, M. R. (1999). Blooms of the cylindrospermopsin containing cyanobacterium, Aphanizomenon ovalisporum (Forti), in newly constructed lakes, Queensland, Australia. Environ Toxicol 14, 167-177.

Spoof, L., Berg, K. A., Rapala, J., Lahti, K., Lepistö, L., Metcalf, J. S., Codd, G. A. \& Meriluoto, J. (2006). First observation of cylindrospermopsin in Anabaena lapponica isolated from the boreal environment (Finland). Environ Toxicol 21, 552-560.

Stamatakis, A. (2006). RAxML-VI-HPC: Maximum likelihood-based phylogenetic analyses with thousands of taxa and mixed models. Bioinformatics 22, 2688-2690.

Stirling, D. J. \& Quilliam, M. A. (2001). First report of the cyanobacterial toxin cylindrospermopsin in New Zealand. Toxicon 39, 1219-1222.

Stucken, K., Murillo, A. A., Soto-Liebe, K., Fuentes-Valdés, J. J., Mendéz, M. A. \& Vasquéz, M. (2009). Toxicity phenotype does not correlate with phylogeny of Cylindrospermopsis raciborskii strains. Syst Appl Microbiol 32, 37-48. 
Stucken, K., John, U., Cembella, A., Murillo, A. A., Soto-Liebe, K. Fuentes-Valdés, J. J., Friedel, M., Plominsky, A. M., Vásquez, M. \& Glöckner, G. (2010). The smallest known genomes of multicellular and toxic cyanobacteria: comparison, minimal gene sets for linked traits and the evolutionary implications. PLoS One 5, e9235.

Stüken, A., Campbell, R. J., Quesada, A., Sukenik, A., Dadheech, P. K. \& Wiedner, C. (2009). Genetic and morphologic characterization of four putative cylindrospermopsin producing species of the cyanobacterial genera Anabaena and Aphanizomenon. J Plankton Res 31, 465480.

Tooming-Klunderud, A., Mikalsen, B., Kristensen, T. \& Jakobsen, K. S. (2008). The mosaic structure of the mcyABC operon in Microcystis. Microbiology 154, 1886-1899.

Valério, E., Pereira, P., Saker, M. L., Franca, S. \& Tenreiro, R. (2005). Molecular characterization of Cylindrospermopsis raciborskii strains isolated from Portuguese freshwaters. Harmful Algae 4, 10441052.
Welker, M. \& von Döhren, H. (2006). Cyanobacterial peptides - nature's own combinatorial biosynthesis. FEMS Microbiol Rev 30, 530-563.

Wilson, K. M., Schembri, M. A., Baker, P. D. \& Saint, C. P. (2000). Molecular characterization of the toxic cyanobacterium Cylindrospermopsis raciborskii and design of a species-specific PCR. Appl Environ Microbiol 66, 332-338.

Wörmer, L., Cirés, S., Carrasco, D. \& Quesada, A. (2008). Cylindrospermopsin is not degraded by co-occurring natural bacterial communities during a 40-day study. Harmful Algae 7, 206-213.

Yilmaz, M., Phlips, E. J., Szabo, N. J. \& Badylak, S. (2008). A comparative study of Florida strains of Cylindrospermopsis and Aphanizomenon for cylindrospermopsin production. Toxicon 51, 130-139.

Zhaxybayeva, O., Gogarten, J. P., Charlebois, R. L., Doolittle, W. F. \& Papke, R. T. (2006). Phylogenetic analyses of cyanobacterial genomes: Quantification of horizontal gene transfer events. Genome Res 16, 1099-1108.

Edited by: C.-C. Zhang 